\title{
Crops for Carbon Farming
}

\author{
Christer Jansson ${ }^{1 *}$, Celia Faiola ${ }^{2}$, Astrid Wingler ${ }^{3}$, Xin-Guang Zhu ${ }^{4}$, \\ Alexandra Kravchenko ${ }^{5}$, Marie-Anne de Graaff ${ }^{6}$, Aaron J. Ogden', \\ Pubudu P. Handakumbura ${ }^{1}$, Christiane Werner ${ }^{7}$ and Diane M. Beckles ${ }^{8}$
}

\begin{abstract}
' Pacific Northwest National Laboratory, Richland, WA, United States, ${ }^{2}$ Department of Ecology and Evolutionary Biology, University of California, Irvine, Irvine, CA, United States, ${ }^{3}$ School of Biological, Earth \& Environmental Sciences and Environmental Research Institute, University College Cork, Cork, Ireland, ${ }^{4}$ National Key Laboratory for Plant Molecular Genetics, Center of Excellence for Molecular Plant Sciences, Chinese Academy of Sciences, Shanghai, China, ${ }^{5}$ Department of Plant, Soil, and Microbial Sciences, Michigan State University, East Lansing, MI, United States, ${ }^{6}$ Department of Biological Sciences, Boise State University, Boise, ID, United States, ${ }^{7}$ Ecosystem Physiology, University Freiburg, Freiburg, Germany,

${ }^{8}$ Department of Plant Sciences, University of California, Davis, Davis, CA, United States
\end{abstract}

\section{OPEN ACCESS}

Edited by:

Massuo Jorge Kato, University of São Paulo, Brazil

Reviewed by:

Christine Helen Foyer, University of Birmingham, United Kingdom

Ricardo da Silva

University of São Paulo, Brazil

*Correspondence: Christer Jansson christer.jansson@pnnl.gov

Specialty section: This article was submitted to Plant Metabolism and Chemodiversity, a section of the journal Frontiers in Plant Science

Received: 01 December 2020 Accepted: 26 April 2021

Published: 04 June 2021

Citation: Jansson C, Faiola $C$, Wingler $A$,

Zhu X-G, Kravchenko A de Graaff M-A, Ogden AJ, Handakumbura PP, Werner $C$ and Beckles DM (2021) Crops for Carbon Farming. Front. Plant Sci. 12:636709. doi: 10.3389/fp/s.2021.636709
Agricultural cropping systems and pasture comprise one third of the world's arable land and have the potential to draw down a considerable amount of atmospheric $\mathrm{CO}_{2}$ for storage as soil organic carbon (SOC) and improving the soil carbon budget. An improved soil carbon budget serves the dual purpose of promoting soil health, which supports crop productivity, and constituting a pool from which carbon can be converted to recalcitrant forms for long-term storage as a mitigation measure for global warming. In this perspective, we propose the design of crop ideotypes with the dual functionality of being highly productive for the purposes of food, feed, and fuel, while at the same time being able to facilitate higher contribution to soil carbon and improve the below ground ecology. We advocate a holistic approach of the integrated plant-microbe-soil system and suggest that significant improvements in soil carbon storage can be achieved by a three-pronged approach: (1) design plants with an increased root strength to further allocation of carbon belowground; (2) balance the increase in belowground carbon allocation with increased source strength for enhanced photosynthesis and biomass accumulation; and (3) design soil microbial consortia for increased rhizosphere sink strength and plant growth-promoting (PGP) properties.

Keywords: carbon budget, carbon farming, plant-microbe interactions, rhizosphere, rhizosphere microbiome, PGPB (plant growth-promoting bacteria), sustainable agriculture

\section{MAIN}

We suggest that significant investments in time and resources should be devoted to developing annual crops for carbon farming. These crops will allocate an increasing amount of carbon to the reproductive sinks, and to the below ground stores for the dual purpose of mitigating global warming due to rising atmospheric $\mathrm{CO}_{2}$ levels and improving soil health for increased crop productivity. From a carbon mass balance perspective, this boils down to increasing soil carbon inputs and storage and decreasing outputs, to attain a net increase in soil carbon storage. We posit that this can be achieved through a comprehensive understanding of carbon fluxes and source-sink interactions in an integrated plant-microbe-soil system. Our rationale for focusing on annual crops are four-fold: (1) according to the U.S. Geological Survey, there is a total of 18.6 million $\mathrm{km}^{2}$ (4.6 billion acres) of cropland globally (U.S. Geological Survey (USGS), 2019), nearly $80 \%$ of which is 
dedicated to annual agriculture, i.e., cereals, legumes, and oilseed crops (Glover et al., 2007); (2) as opposed to perennials, which require a time commitment of several years, annual crops are more amenable to implementation and deployment of novel and specifically designed crop varieties; (3) perennial plants already invest a substantial portion of their photosynthate in root biomass, and it can be expected that the impact on improved soil carbon status from re-designing perennials will be of less significance compared to efforts on annual crops; and (4) in many cases, annual cropping systems have resulted in a soil carbon debt and, therefore, may be particularly receptive to efforts that aim at improving the soil carbon budget (Griscom et al., 2017; Houghton and Nassikas, 2017; Sanderman et al., 2017).

The soil carbon pool with 2,500 gigatons (GT; 1 GT $=1$ billion metric tons) in the top $3 \mathrm{~m}$ is 3.3 times the size of the atmospheric pool of $760 \mathrm{GT}$ and includes 1,550 GT of soil organic carbon (SOC) and $950 \mathrm{GT}$ of soil inorganic carbon (Lal, 2004a, 2008; Jansson et al., 2010; Figure 1). The SOC pool in the first $1 \mathrm{~m}$ and the top $20 \mathrm{~cm}$ of the soil profile is 1,500 and 615 GT, respectively (Sanderman et al., 2010; Guo et al., 2016). The primary carbon exchange between the atmosphere and the terrestrial ecosystem is the incorporation of $\mathrm{CO}_{2}$ at 123 GT year $^{-1}$ into plant biomass through photosynthesis, of which $3 \mathrm{GT}$ year $^{-1}$ emanates from anthropogenic activities (DOE, 2008)11, and the release of $\mathrm{CO}_{2}$ from previously fixed carbon through plant and microbial respiration at 60 and 60 GT year ${ }^{-1}$, respectively (Jansson et al., 2010; Abdullahi et al., 2018). Currently, terrestrial ecosystems are a net carbon sink of $3 \mathrm{GT}_{\text {year }}{ }^{-1}$, thereby roughly buffering one third of the annual increase of atmospheric $\mathrm{CO}_{2}$ concentration from greenhous gas (GHG) emissions (Le Quere et al., 2018). Consequently, a large fraction of the $\mathrm{CO}_{2}$ that is captured as photosynthate is rapidly returned to the atmosphere, and only a minor fraction enters the stable pool of soil carbon. Thus, manipulation of the soil carbon budget, if only by a few percent, represents significant potential for climate change mitigation (Paustian et al., 2016).

Agroecosystems constitute more than one third of the world's arable land and they contribute $10-14 \%$ of global anthropogenic greenhouse gas emissions, primarily from enteric fermentation (methane), application of synthetic fertilizers (nitrous oxide), and tillage $\left(\mathrm{CO}_{2}\right)$ (Jantke et al., 2020). However, agricultural ecosystems also have the potential to store a vast amount of soil carbon (Sanderman and Baldock, 2010; Abdullahi et al., 2018), up to 1 GT year ${ }^{-1}$, which would offset around $10 \%$ of the annual GHG emissions of 8-10 GT year ${ }^{-1}$. As stated by the Carbon Cycle Institute, "Agriculture is the ONE sector that has the ability to transform from a net emitter of $\mathrm{CO}_{2}$ to a net sequesterer of $\mathrm{CO}_{2}$-there is no other human managed realm with this potential" (The Carbon Cycle Institute, 2020). There are numerous land management practices that can be adopted to increase soil carbon storage in agroecosystems, such as changes in crop rotations, tillage, fertilizer management, and organic amendments (Lal, 2004a). Maybe the most effective means for increasing soil carbon sequestration is through changing land cover, such as converting annual cropland to forest or perennial grasses. One caveat with such land use conversions is that it would have negative consequences for biomass yield from the crops that are displaced. One, virtually untapped, alternative option is to select and design annual crop plants that allocate an increased amount of carbon to belowground biomass and root exudates or rhizodeposits.

Soil organic carbon (as a proxy for soil organic matter) plays two roles as we tackle the challenge of achieving sustainable agroecosystems in the coming decades; by increasing crop productivity and by sequestering atmospheric carbon. SOC promotes crop productivity by improving nutrient retention and water holding capacity, by facilitating efficient drainage and aeration, by minimizing loss of topsoil via erosion, and by providing substrates for the soil microbiomes (Lal, 2004a; Sanderman and Baldock, 2010; Berazneva et al., 2019). SOC can be sequestered in persistent pools, e.g., by conversion to biochar or through organo-mineral and organo-metal interactions, with a residence time from decades to thousands of years to millennia (Jansson et al., 2010; Sanderman et al., 2010; Abdullahi et al., 2018). SOC can also be transformed to soil inorganic compounds such as calcium and magnesium carbonates for long-term storage (Guo et al., 2016). The rational design, development, and deployment of crops tailored for carbon farming will depend in part on our ability to model metabolic fluxes of carbon and nitrogen, understand their control, and subsequently apply this insight to reconfigure source-sink interactions and carbon allocation pathways in integrated plant-microbe-soil systems through genome engineering and editing. There is plenty of ongoing efforts in this space to draw from, such as the development of metabolic flux models (Sweetlove and Ratcliffe, 2011; Grafahrend-Belau et al., 2013; Lakshmanan et al., 2016; Töpfer et al., 2020) and genome-scale metabolic networks (Matthews and Marshall-Colon, 2021).

\section{WHERE DOES THE CARBON GO? - A MASS BALANCE ACCOUNT}

A representation of carbon fluxes in a terrestrial ecosystem is depicted in Figure 2. The mass balance for carbon (and any material) in the ecosystem can be accounted for by the equation

$$
\text { Input }- \text { Output }=\text { Storage }
$$

For carbon, Eq (1) can be summarized as follows:

Inputs: Photosynthesis; Soil amendments

Outputs: Plant and microbial respiration; Emissions of volatile organic compounds (VOCs)

Storage: Plant and microbial biomass; Soil carbon as SOC and SIC pools

The soil carbon content is governed by the balance between photosynthetic inputs via liter and root exudation and amendments such as manure and compost, and outputs through heterotrophic respiration from roots and microbes and via VOC emissions.

Carbon allocation is a crucial physiological process where assimilated atmospheric $\mathrm{CO}_{2}$ (photosynthate) is shifted between respiration and biomass production, transient and enduring tissues, and aboveground and belowground components. Functional, or optimal equilibrium theory holds that plants 


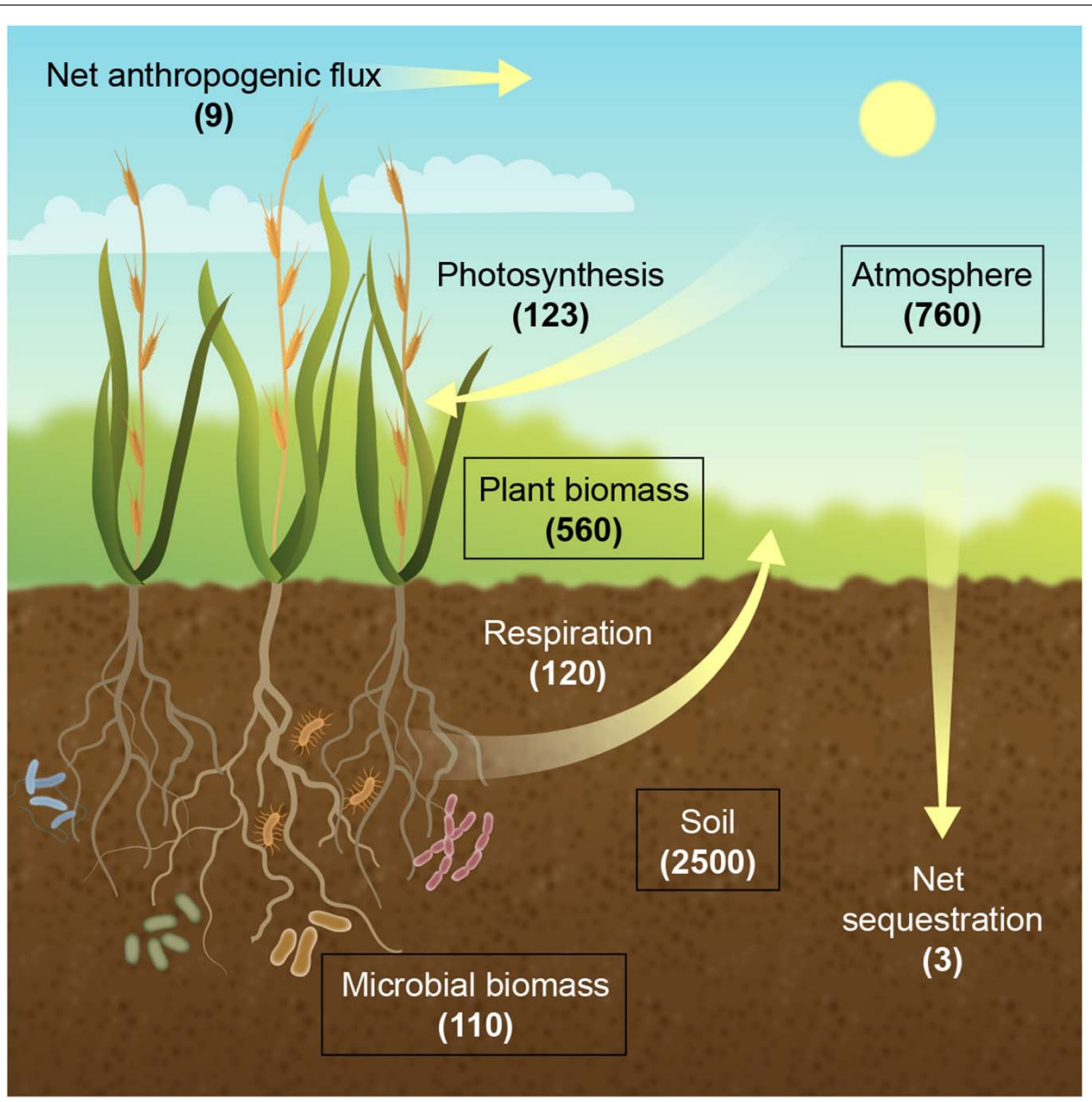

FIGURE 1 | The terrestrial carbon (C) cycle. Carbon stocks (boxes) are shown as gigatons (GT), and fluxes (arrows) are shown in GT per year. Respiration refers to accumulated plant and microbial respiration.

allocate resources among organs to optimize whole-plant fitness (Thornley, 1972; Bloom et al., 1985; Poorter and Nagel, 2000). Thus, allocation of recent photosynthate between aboveground and belowground biomass for a given plant will shift in response to environmental variables such as soil moisture, light, and nutrient availability. Evidence from field studies indicates that plants allocate relatively more carbon to shoots under light limitation and to roots under water and/or nutrient limitation.

Plants allocate considerable amounts (20-30\%) of recent photosynthate to their belowground biomass. About $50 \%$ of the translocated carbon is used for root growth, while a substantial fraction of this carbon (up to 30\%) is further released to the rhizosphere, either as direct root deposition through exudation, sloughed root cap cells, or via mycorrhiza, or is lost through respiration (Lorenz et al., 2008; Turner et al., 2013; Kaiser et al., 2015). Both root exudation and transfer to mycorrhizal fungi occur rapidly after photosynthesis, ranging from a few hours in grasses to a few days in trees (Kaiser et al., 2015). Root exudation stimulates microbial decomposition of SOM, which in turn improves nutrient availability along the rhizosphere. Carbon transfer to mycorrhizal fungi benefits the plant through direct nutrient transfer from the fungal hyphal network. In both cases, the plant's investment in belowground carbon allocation is rewarded with increased nutrient availability, in particular nitrogen and phosphorus, as well as enhanced tolerance to abiotic stress such as drought, heat, and salinity (Kaiser et al., 2015; Begum et al., 2019).

A substantial portion of the photosynthate can be released to the atmosphere in the form of VOCs, with isoprenoids representing the dominant compound class (Guenther et al., 2012). The amount of carbon re-emitted as isoprene (with this single compound representing about half of all isoprenoid emissions) generally comprises $1-3 \%$ of NPP but can significantly increase up to $50 \%$ given unfavorable environmental conditions, particularly when photosynthetic carbon uptake is low (Loreto and Sharkey, 1993; Sharkey and Loreto, 1993; Harley et al., 1999). Thus, a larger fraction of fixed carbon is re-emitted under conditions of moderate plant stress while total emissions decrease under extreme stress (Holopainen and Gershenzon, 2010; Niinemets, 2010; Niinemets et al., 2013). These VOCs are highly reactive and readily participate in atmospheric oxidation chemistry (Atkinson and Arey, 1998, 2003). Oxidation products of these reactions undergo gas-particle partitioning and contribute to the formation of 


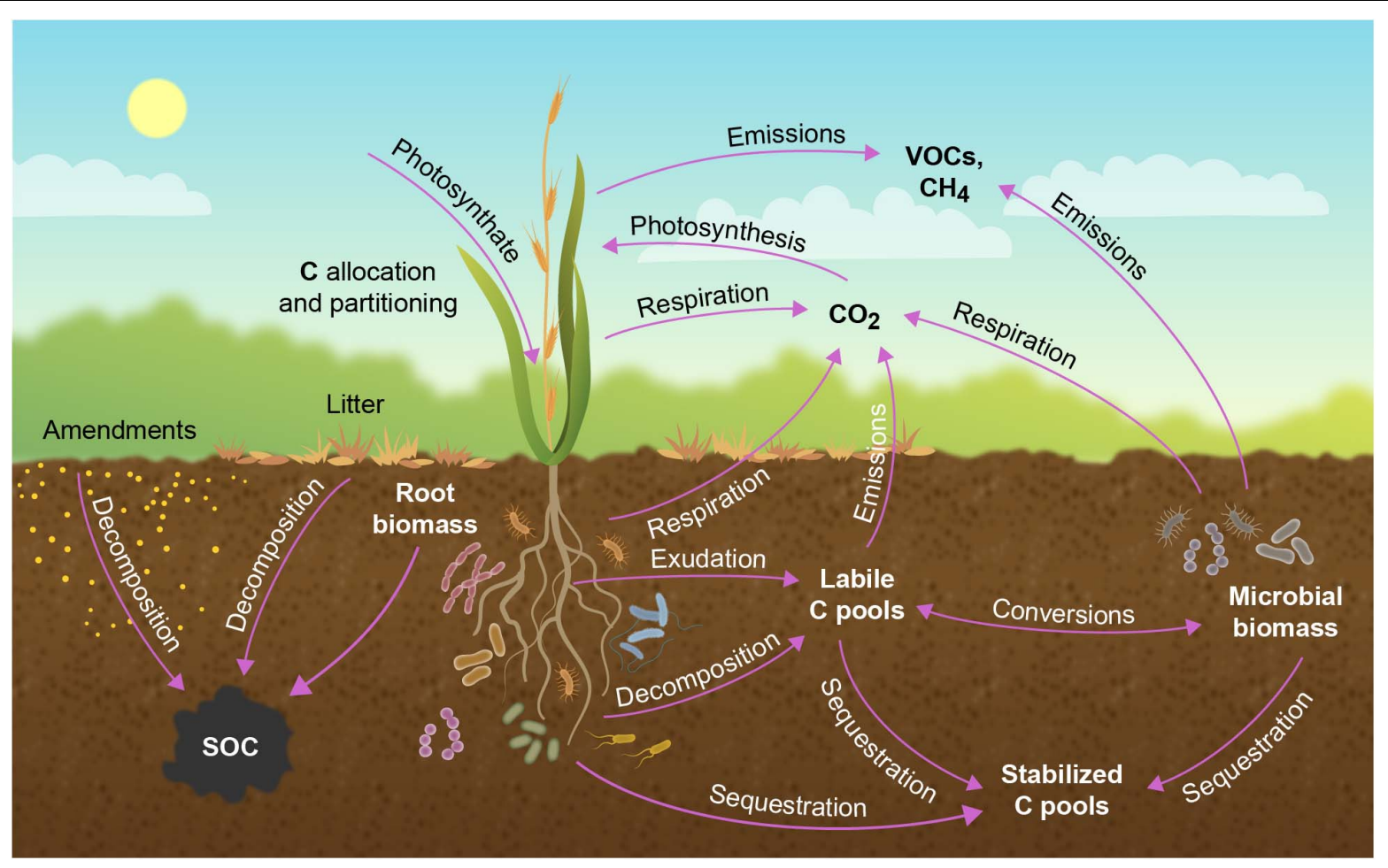

FIGURE 2 | Transfer of atmospheric $\mathrm{CO}_{2}$ into biotic and pedologic carbon (C) pools the plant ecosystem. Carbon enters the soil as root exudates or via decomposition of root or aboveground biomass. In the soil, $\mathrm{C}$ exists in root or microbial biomass, as bioavailable labile organic $\mathrm{C}$, or as more recalcitrant $\mathrm{C}$. Carbon exits the soil as direct emissions, or via root or microbial respiration, with microbial-mediated soil respiration being the major source of $\mathrm{CO}_{2}$ from terrestrial ecosystems. Carbon is also lost from the ecosystem as volatile organic compounds (VOCs) and methane $\left(\mathrm{CH}_{4}\right)$. Modified from Jansson et al. (2018).

atmospheric particulate matter, called secondary organic aerosol (SOA; Hallquist et al., 2009; Mohr et al., 2019). Atmospheric aerosols influence radiative transfer through the atmosphere directly by scattering and absorbing incoming solar radiation and indirectly by contributing to cloud formation processes (Kerminen et al., 2005; Spracklen et al., 2008; Riipinen et al., 2012). The type of volatiles emitted from different plants under healthy and stressed conditions can vary greatly with substantial impacts on SOA formation (Mentel et al., 2013; Joutsensaari et al., 2015; Yli-Pirilä et al., 2016; Zhao et al., 2017; Faiola et al., $2018,2019)$. This influences the quantity and characteristics of the light available for plant use, including the ratio of diffuse to direct light with subsequent impacts on NPP (Rap et al., 2018). These relationships are illustrated schematically in Figure 2 and highlight potential feedback mechanisms between the soil-plant-atmosphere system mediated through VOC emissions and aerosol production. Significant impact of VOC-mediated secondary aerosol formation on atmospheric processes and human health have been observed e.g., from the conversion of crop fields to isoprene emitting bio-fuel plants (e.g., poplar) (Ashworth et al., 2013). Accounting for these feedbacks in making decisions about carbon farming will be particularly important under future climate scenarios with increased drought stress, which could increase the overall proportion of carbon re-emitted in the form of VOCs. We caution, that most VOC studies to date have been performed in perennials, and the relevance of aspects discussed above to annual crops such as sorghum, corn, wheat, and soybean, needs to be addressed through large-scale assessments.

\section{INCREASE ROOT AND RHIZOSPHERE SINK STRENGTH}

Soil carbon stocks can be augmented by increasing the rate of carbon additions to the soil, by increasing retention of new carbon deposited in soil, or by reducing the rate of decomposition of SOC already present in the soil. A potential path to increased soil carbon stocks is the employment or development of crop cultivars that input a greater quantity of carbon into the soil through their roots. Just like sink strength of developing grains is a key determinant of grain yield, utilization of carbon for root growth determines root sink strength and belowground accumulation as SOC (Figure 3). This may be achieved by a greater root biomass, or by a greater surface area of roots that actively release carbon into soil. For example, switchgrass cultivars with a greater proportion of fine roots, and a relatively large specific root length enhanced soil carbon input in bioenergy cropping systems (Adkins et al., 2016). However, for long-term sequestration of this carbon, it is essential that it is retained in soil, either through associations with soil minerals, via conversion to carbonate 

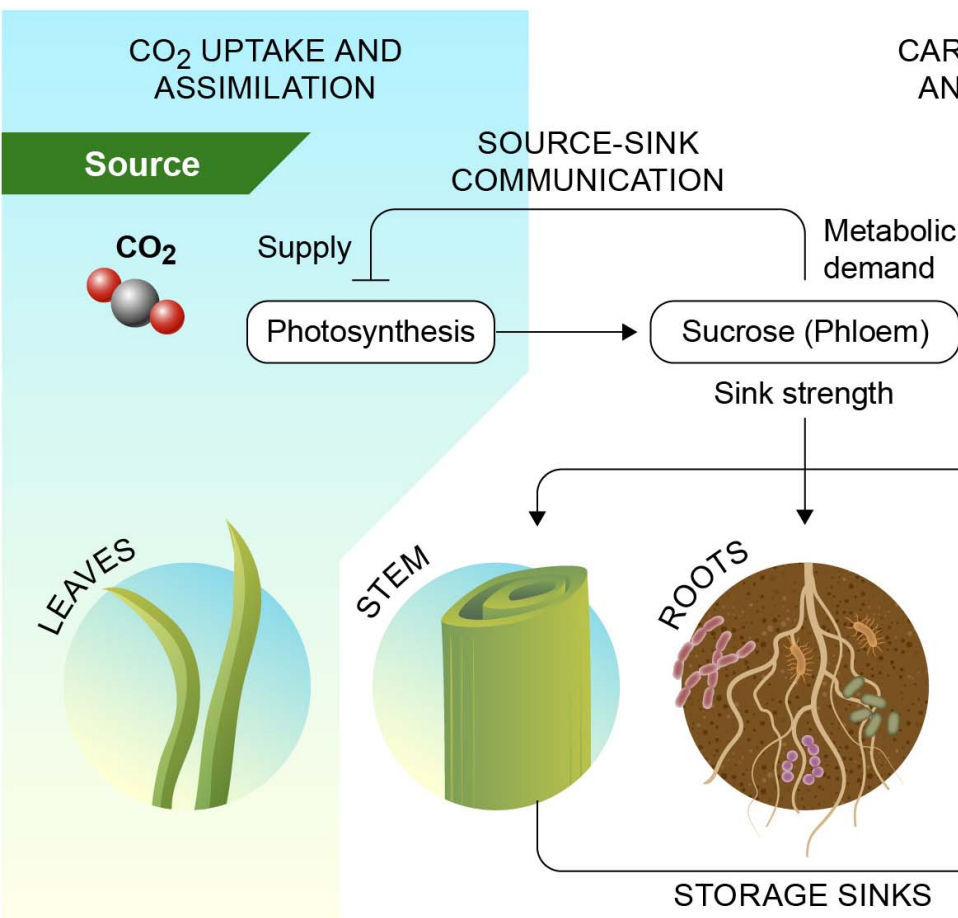

\section{CARBON ALLOCATION AND PARTITIONING}

\section{Sink}

FIGURE 3 | Source-sink interactions of photosynthate production and utilization. Source-sink interactions link carbon sources such as mature leaves to sinks such as roots and seeds and mediates feedback inhibition of photosynthesis via perceived sink demand. Sink strength of the rhizosphere is contributed by the root biomass and associated microbial communities, including arbuscular mycorrhiza. Reprinted from Fan et al. (2008).

minerals or recalcitrant organic carbon like charcoal, or via reduction of microbial respiration, i.e., an increase in microbial carbon-use efficiency. Growing deeper root systems presents another pathway by which soil carbon input and retention may be enhanced. Carbon deposited at depth may have a greater mean residence time, because decomposition rates are slower in deeper soil profiles compared to surface horizons, promoting long-term soil carbon storage. Additionally, deeper roots can to some extend buffer the impacts of droughts, thus further increasing carbon uptake. If developed, such plants could be deployed rapidly, and at scale, due to continuous genetic turnover and active land management in agricultural croplands. Improving plants to increase soil carbon sequestration represents an untapped and economic net carbon sink with significant economic potential (Paustian et al., 2019a). A rationale for this concept was presented by Kell (2012). Further, under scenarios of elevated atmospheric $\mathrm{CO}_{2}$ levels due to climate change, $\mathrm{C}_{3}$ crops that are typically $\mathrm{CO}_{2}$ limited may instead face nitrogen limitation, making a larger root biomass even more advantageous.

In an analysis to support a new program launched by the US Department of Energy, Paustian et al. (2016) performed a "bounding analysis" to estimate what level of soil carbon increase and total greenhouse gas mitigation (including $\mathrm{N}_{2} \mathrm{O}$ emissions) might be possible based on specifying feasible increases in total root mass and changing root depth distributions toward those found in perennial grasses. They estimated that widespread adoption of annual crop phenotypes designed to have deeper and larger root systems could yield soil carbon stock increases of 0.5 GT $\mathrm{CO}_{2}$ ha $^{-1}$ year $^{-1}$ on current US cropland (Paustian et al., 2016, 2019a).

While it is well known that root systems play a major role in SOC supply and storage, exactly which root characteristics are important for maximizing SOC gains and for ensuring long-term carbon storage is not obvious. High root-derived carbon inputs are a necessary-but-not-sufficient prerequisite for soil carbon gains. For example, greater root biomass and root exudation, stimulated by higher $\mathrm{CO}_{2}$ levels, do not necessarily translate into high soil carbon gains, a phenomenon explained by enhancement of microbial activity and enhanced priming of old soil organic matter (Hungate et al., 1997; Pendall et al., 2004; Phillips et al., 2012) (yet see Jastrow et al., 2005). A nine-year-old field trial comparing two perennial herbaceous systems, monoculture switchgrass and highly biodiverse native succession vegetation, demonstrated that, even though switchgrass root biomass more than 10-fold exceeded that of native vegetation, improvements in SOC levels under switchgrass were noticeably lower (Kravchenko et al., 2019). These examples suggest that it is not at all certain that breeding for higher root biomass is the answer to faster and more effective SOC storage. Among the plant characteristics that should be considered as such that might lead to SOC gains are: (1) physical characteristics of the root system architecturenot only the total root biomass, but also the root morphology auspicious for soil structure formation (Bardgett et al., 2014; 
Postma et al., 2017; Kravchenko et al., 2019; Voges et al., 2019); (2) quantities of carbon entering the soil in a form of rhizodeposits during root growth and live functioning (Kuzyakov and Domanski, 2000; Bengtson et al., 2012; Mwafulirwa et al., 2016); (3) chemical composition of root tissues and exudates (Keiluweit et al., 2015; Naveed et al., 2017); and (4) development of a rhizosphere microbiome able to convert root carbon inputs into protected SOC with greater efficiency (Lange et al., 2015).

Yet, possibly none of these factors matters by themselves, but, instead, a favorable combination of all is needed to generate SOC gains (Yang et al., 2019). As alluded to above, how much carbon stays in soil depends on how much is put in and how much remains protected. Recent studies have revealed that low molecular weight root exudates are particularly important for SOC formation and retention. This is because they promote microbial residue formation, and microbially derived compounds make up a large proportion of stable SOC (Cotrufo et al., 2013; Kallenbach et al., 2016). However, many questions remain regarding the interactions among root exudation, the microbial community structure, its physiology, and ultimately impacts on the ratio of carbon turned into microbial biomass versus the amount of carbon released from soil as $\mathrm{CO}_{2}$. The ideal scenario might be large amounts of high-quality rootderived carbon inputs accompanied by formation of the pore architecture favorable for protecting the new carbon from further decomposition (Kravchenko et al., 2019), i.e., by greater heterogeneity of the pore space (De Deyn et al., 2011).

It also would need to be considered that, even within the same species/genotype, the specific contributions of individual plants can depend on their age, their growth conditions in terms of nutrient and water supply and presence of stresses (Uren, 2007; Helliwell et al., 2019), and the competition with neighboring plants of the same or different species/genotypes (Fan et al., 2008). In perennial grassland vegetation complementarity of high plant diversity has been shown to be highly beneficial to soil carbon storage; high diversity treatments performed significantly better than any monocultures (Yang et al., 2019) and biodiversity in terms of greater number of plant species appeared to be more important than the plant biomass inputs (Steinbeiss et al., 2008). Those are facets that will need to be considered in deciding where to direct the engineering efforts in modifying root systems of annual plants to increase their ability to protect SOC.

In addition to plant diversity and root morphology, altering the quantity and composition of root exudates to increase SOC is an attractive focus area for two reasons. First, predictably controlling total root exudate production can directly impact the source-sink relationship between root and aerial plant organs. Second, the composition of root exudates impacts rhizosphere microbial community succession, and therefore allows breeders a way to potentially steer composition of crop rhizobiomes in favor of microbes that are better carbon sinks, improve soil characteristics, or increase longevity of SOC. The role of AM fungi as carbon sinks for plants is well documented (Churland and Grayston, 2014; Gorzelak et al., 2015; Kaiser et al., 2015), and there is evidence that bacteria and other members of the rhizospheric microbiome provide similar functions (Trivedi et al., 2013; Kallenbach et al., 2016). For example, it was recently shown that plant-derived coumarins in root exudates limit growth of particular bacterial taxa in the rhizobiome (Voges et al., 2019). Thus, controlling total root exudate production as a strategy for increasing root sink strength, as well as exudate composition as a strategy to influence rhizosphere community dynamics should be explored as an option for allocating more carbon to the soil for long-term storage. Here, tipping the compositional balance of the rhizosphere microbiome in favor of AMF may provide the necessary benefits for yield as well as for soli carbon storage (Berger, 2019; Zhang et al., 2019).

It is well documented that the plant microbiome exerts a plethora of plant growth-promoting (PGP) effects that benefit their host plants, such as conferring enhanced abiotic and biotic stress tolerance and improved nutrient acquisition, including $\mathrm{N}$-fixation (Ahkami et al., 2017). Thus, tailoring a rhizosphere microbiome to combine an increase in sink strength with enhanced PGP properties should go a long way toward achieving the dual goal of improving the soil carbon budget and boost productivity (Figure 4). We envision that, while designing microbiomes with assigned functional properties will leverage the enormous existing soil microbial diversity, it will also encompass the possibility of employing genome-engineering/editing to construct highly specific synthetic microbial communities (SynComs) that are obligate symbionts to the plant host, so as to provide a biocontainment strategy. The design and utility of SynComs in improving plant traits were recently discussed in de Souza et al. (2020).

\section{... WITHOUT JEOPARDIZING YIELD}

Designing crops for carbon farming and improving the soil carbon budget is unlikely to be a viable approach unless farmers see a financial return. Although such returns could take the form of tax credits and cap-and-trade programs, this does not provide a sustainable, long-term solution. While improving soil health by increasing the SOC pool and benefiting from increased PGP effects of synthetic rhizosphere microbiomes will ultimately favor plant productivity, it is unlikely to maintain, let alone increase, crop yield in plants designed for funneling a substantial portion of photosynthate to the soil. Therefore, carbon farming will also need to include measures to enhance photosynthetic energy conversion efficiency and hence biomass production. Several such options have been explored (Ort et al., 2015; Kromdijk et al., 2016; Jansson et al., 2018; South et al., 2019). In particular, an increase in the speed of recovery from photoprotective state resulted in increased photosynthesis and biomass production (Kromdijk et al., 2016). Similarly, engineering photorespiratory bypasses can result in increased $\mathrm{CO}_{2}$ levels around Rubisco and decreased photorespiratory lost (South et al., 2019). Modification of leaf biochemical and anatomical features and decreasing the resistance of $\mathrm{CO}_{2}$ diffusion to the site of its fixation around Rubisco has the potential to increase source activity without increase water loss through stomata (Flexas et al., 2016). Increasing the speed of adjustment of stomatal conductance or activities of Calvin Benson cycle under fluctuation light can also increase photosynthetic efficiency and crop water use efficiency 


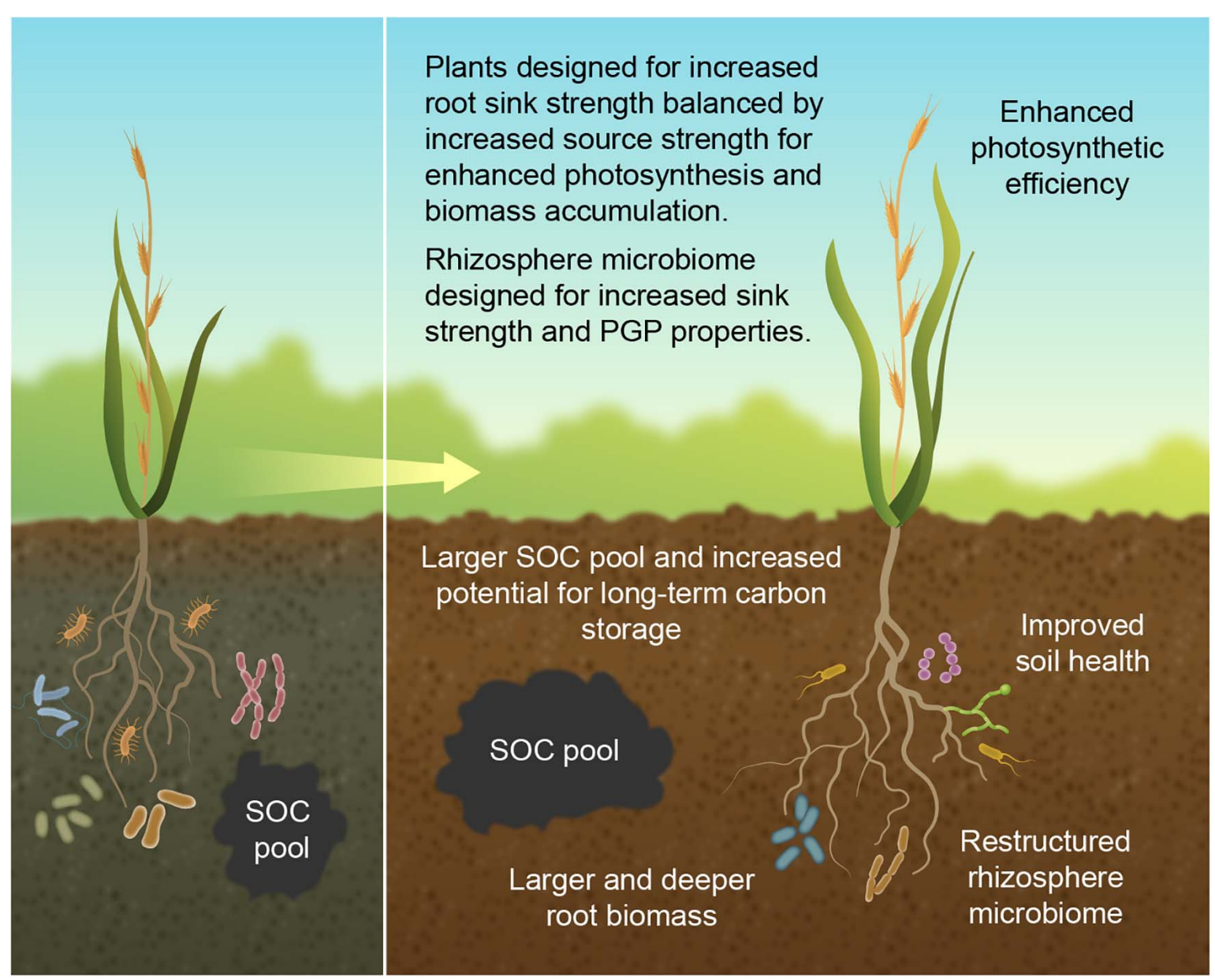

FIGURE 4 | Rationale for designing an integrated plant-microbe-soil system with the dual goal of improving the soil carbon budget while maintaining crop yield, showing current crop (left panel) and desired crop ideotype (right panel). Larger root biomass confers increased sink strength that funnels more carbon to the soil, and deeper roots increase the likelihood for long-term soil carbon storage. Custom-made rhizosphere microbiomes are designed to further augment the demand for belowground carbon, thereby increasing the rhizosphere sink strength, while also providing PGP properties. To complement promotion of plant productivity from improved soil health, PGP microbes, and enhanced photosynthesis by increased sink demand, plants are also designed for increased source strength to further enhance photosynthesis and biomass accumulation.

(Lawson and Blatt, 2014; Taylor and Long, 2017). In addition to these, radical manipulations of photosynthetic machinery, such as engineering $\mathrm{CO}_{2}$ concentrating mechanisms (CCMs), such as $\mathrm{C}_{4}$ photosynthetic machinery or cyanobacterial carboxysome CCM into $\mathrm{C}_{3}$ crops also hold great potential to dramatically increase source activity (Long et al., 2015). The major assumption here is that to have these options useful in increasing crop yield and root biomass, the increased photosynthetic rates will not result in decreased allocation to root tissues. Indeed, when plants of the same functional type are considered, relatively conserved root:shoot ratios are obtained, though plants of different functional types, or grown under different environment, or at different growth stages show drastically different root:shoot ratios (Mokany et al., 2006). We recognize that our knowledge of biochemical pathways in plants are often not sufficiently complete that we can reasonably predict the consequences of changing the expression of targeted genes. Here, open-ended forward genetics approaches through genome editing may be useful as a complement to rational design (Zsögön et al., 2017; Andres et al., 2019; Belcher et al., 2020).

The growth and yield of crops are not solely limited by photosynthesis in mature leaves (source strength) but also by the allocation pattern of photosynthates to other organs, i.e., sink strength. Importantly, if sink strength does not keep up with source strength, this can result in the accumulation of carbohydrates in the leaves and feedback inhibition of photosynthesis (White et al., 2016; Jansson et al., 2018; Figure 3). Since elevated atmospheric $\mathrm{CO}_{2}$ concentration increases source more than sink strength, it will become even more important to focus on enhancing sink strength alongside photosynthesis in crop improvement (Chang and Zhu, 2017). Increased yield and plant carbon capture could be achieved by optimizing the regulatory processes that determine sink strength in heterotrophic organs, in combination with overcoming the 
feedback inhibition of photosynthesis. It is conceivable then, that an increased sink strength in the roots or rhizosphere to draw more carbon to the soil can be combined with maintained, or even enhanced, yield by capitalizing on elevated atmospheric $\mathrm{CO}_{2}$ levels and/or by uncoupling photosynthesis from feedback inhibition by sink demand. This is particularly true for $\mathrm{C}_{3}$ crops that will directly benefit from increased source strength by rising $\mathrm{CO}_{2}$ concentrations.

In considering the scenario depicted above, it is critical to understand that the extent to which a crop plant is source or sink limited depends on its developmental stage and the environment and also varies between species and genotypes. Annuals typically transition from sink to source limitation during development when they switch from vegetative to reproductive growth (Arp, 1991; Burnett et al., 2016), although cereals such as wheat and barley can remain sink limited during reproduction (Serrago et al., 2013). Perennials, in contrast, may evade sink limitation and acclimation to elevated $\mathrm{CO}_{2}$ through developmental plasticity (Burnett et al., 2016).

Another important aspect is the diversification of crop rotations and annual coverage. Long-term experiments and recent eddy covariance measurements have shown contrasting results regarding the $\mathrm{CO}_{2}$ sink or source function of croplands, which vary between cultivar and management techniques (Poyda et al., 2019). The carbon uptake during the growing season can be compensated by stronger heterotrophic respiration from bare soils after harvest (Schmidt et al., 2012). Inclusion of cover crops (rather than allowing a fallow period during the winter months) can increase the SOC stock of cropland soils and thus be another effective measure to compensate $\mathrm{CO}_{2}$ emissions. Thus, cover cropping has been shown to improve the net ecosystem carbon balance by replacing the bare fallow period when carbon is lost by soil respiration, by an additional period of carbon assimilation (Lal, 2004b). A recent meta-analysis has estimated a potential global SOC sequestration of $0.12 \mathrm{Pg} \mathrm{C}_{\text {year }}{ }^{-1}$, which would compensate for $8 \%$ of the direct annual greenhouse gas emission from agriculture (Poeplau and Don, 2015). Intercropping has often been applied to either improve soil nutrition, e.g., with $\mathrm{N}$-fixing plants, or inversely to secure uptake of excess $\mathrm{N}$ and reduce soil $\mathrm{N}$ leaching, and enhance $\mathrm{P}$ and soil microbial communities. Thus, cover crops have been mainly investigated for their capacity to improve soil quality (Hallama et al., 2019). Another untapped possibility to mitigate climate change effects rests upon engineering cover crops with deeper root systems and enhanced soil carbon allocation provides.

\section{THE NEED FOR MODELING FLUXES}

Development of comprehensive, highly mechanistic systems models of crop growth and development (Chang and Zhu, 2017) to guide the design new integrated crop-microbe systems or agronomic practices is highly desirable. For example, since roots are heterotrophic organs, a larger root biomass will further increase an already significant root respiration. The ability to accurately predict carbon losses through respiratory fluxes becomes an important tool in crop design. More generally, around $50 \%$ of assimilated photosynthate is subsequently lost to respiration (Amthor et al., 2019). Minimizing "non-essential" respiratory activity leading to unnecessary $\mathrm{CO}_{2}$ release is unlikely to have been subject to selection pressure during evolution or being considered in crop breeding programs and cutting this large loss could complement and reinforce other efforts in designing crops for enhanced productivity. Such strategies to decrease respiratory cost could include: (1) slow unnecessary protein turnover; (2) replacing, relocating, and/or rescheduling metabolic activities; (3) suppressing futile cycles; (4) improving ion transport efficiency (Amthor et al., 2019). A comprehensive understanding of short- and long-term carbon $\left({ }^{13} \mathrm{C}\right)$ and nitrogen $\left({ }^{15} \mathrm{~N}\right)$ fluxes within a model cereal could be instructive, displaying the proportion of carbon allocated to the source and sinks (grain and roots), and the percentage released to the soil and the atmosphere. This integrated understanding of carbon movement would be viewed in relation to plant growth, biomass, yield, and plant productivity. This data would serve as a blueprint from which to understand developmental and environmental shifts in carbon allocation, to begin engineering strategies, and to better support predictive models. For example, toward understanding the effects of reduced nitrogen, higher $\mathrm{CO}_{2}$, drought, and heat, singly, and in different combinations, on the plant-microbeenvironment carbon continuum. Another example to highlight is the need for measuring and predicting fluxes relates to the emissions of $\mathrm{N}_{2} \mathrm{O}$ (the most potent biogenic greenhouse gas on a per mass basis) resulting from increased nitrogen inputs when needed to match elevated atmospheric $\mathrm{CO}_{2}$ levels. Models are also required that account for sink stimulation of photosynthesis to assess the extent by which carbon costs incurred as part of interactions or symbioses with the rhizosphere microbiome are compensated for by enhanced photosynthesis and biomass production (Kaschuk et al., 2009). Development of predictive metabolic models requires detailed maps of metabolic fluxes in different organs and across the whole integrated plantmicrobe-soil-atmosphere system under different conditions, and how these change under changed environmental or internal conditions. This represents a major area of research for the future plant environmental and molecular physiology. Metabolic flux analysis is widely used to study microbial communities and it can be adapted to derive comprehensive map of photosynthate and compound transfer between different organs in crops and other plants (Wiechert, 2001; Ma et al., 2014).

\section{CLOSING REMARKS}

Carbon farming aims to improve the rate at which $\mathrm{CO}_{2}$ is removed from the atmosphere and converted to plant material and soil organic matter. The positive outcome of this ambition is two-fold; improved soil health, which, in turn, promotes crop productivity, and increased potential for long-term carbon storage to mitigate greenhouse gas emissions. In this perspective we argue that crops designed for carbon farming should be endowed with the following attributes: (1) increased belowground carbon allocation for larger and deeper root biomass; (2) interactions with a 
tailored, synthetic soil microbiome for increased rhizosphere sink strength and enhanced PGP properties that facilitate nutrient acquisition and water-use efficiency; and (3) increased source strength for enhanced photosynthesis and biomass accumulation. This represents an ambitious initiative that entails genome engineering/editing of the integrated plant-microbe-soil system, supported by systems-level multi-omics analysis, and metabolic flux analysis and modeling. It will also be important to engage international breeding programs and cull resources from extensive germplasm collections (Lenaerts et al., 2019; VossFels et al., 2019). This becomes particularly relevant in efforts to integrate and balance traits for soil carbon deposition with biomass yield and stress tolerance and resilience.

We conclude by recognizing that soil carbon storage is not an infinite solution to curtailing greenhouse gas emissions, primarily since soils have an upper limit or saturation level of carbon (Six et al., 2002; Paustian et al., 2019b). We recognize the challenges associated with societal acceptance of genomeedited crops and new agronomic practices in implementing crops for carbon farming. However, carbon farming offers the opportunity in the next coming decades to capitalize on the substantial potential inherent in combining agriculture with the rhizosphere microbiome in promoting soil carbon sequestration. As such, designing crops for carbon farming aligns with the consensus from the Paris climate agreement, stating that economically optimal paths to reach the Paris goal in limiting global warming not only requires cutting emissions

\section{REFERENCES}

Abdullahi, A. C., Siwar, C., Shaharudin, M. I., and Anizan, I. (2018). Carbon Capture, Utilization and Sequestration, ed. R. K. Agarwal (London: IntechOpen).

Adkins, J., Jastrow, J. D., Morris, G. P., Six, J., and de Graaff, M. A. (2016). Effects of switchgrass cultivars and intraspecific differences in root structure on soil carbon inputs and accumulation. Geoderma 262, 147-154. doi: 10.1016/j. geoderma.2015.08.019

Ahkami, A., White, I., Handakumbura, R. A., and Jansson, C. (2017). Rhizosphere engineering: enhancing sustainable plant ecosystem productivity in a challenging climate. Rhizosphere 3, 233-343. doi: 10.1016/j.rhisph.2017. 04.012

Amthor, J. S., Bar-Even, A., Hanson, A. D., Millar, A. H., Stitt, M., Sweetlove, L. J., et al. (2019). Engineering strategies to boost crop productivity by cutting respiratory carbon loss. Plant Cell 31, 297-314.

Andres, J., Blomeier, T., and Zurbriggen, M. D. (2019). Synthetic switches and regulatory circuits in plants. Plant Physiol. 179, 862-884. doi: 10.1104/pp.18. 01362

Arp, W. J. (1991). Effects of source-sink relations on photosynthetic acclimation to elevated Co2. Plant Cell Environ. 14, 869-875. doi: 10.1111/j.1365-3040.1991. tb01450.x

Ashworth, K., Wild, O., and Hewitt, C. N. (2013). Impacts of biofuel cultivation on mortality and crop yields. Nat. Clim. Change 3, 492-496. doi: 10.1038/ Nclimate 1788

Atkinson, R., and Arey, J. (1998). Atmospheric chemistry of biogenic organic compounds. Acc. Chem. Res. 31, 574-583. doi: 10.1021/ar970143z

Atkinson, R., and Arey, J. (2003). Atmospheric degradation of volatile organic compounds. Chem. Rev. 103, 4605-4638. doi: 10.1021/cr0206420

Bardgett, R. D., Mommer, L., and De Vries, F. T. (2014). Going underground: root traits as drivers of ecosystem processes. Trends Ecol. Evol. 29, 692-699. doi: $10.1016 /$ j.tree.2014.10.006 of greenhouse gasses but must also include negative emissions technologies, such as stimulating the soil to store more carbon (Economist, 2017).

\section{DATA AVAILABILITY STATEMENT}

The original contributions presented in the study are included in the article/Supplementary Material, further inquiries can be directed to the corresponding author.

\section{AUTHOR CONTRIBUTIONS}

CJ conceived the work. All authors contributed to the article and approved the submitted version.

\section{FUNDING}

This work was initiated and supported by the Environmental Molecular Science Laboratory (EMSL) as part of the 2019 EMSL Integration Meeting (CJ, $\mathrm{AO}$, and $\mathrm{PH})$, the general program of National Natural Science Foundation of China (31870214; X-GZ), Israel-US Binational Agriculture Research Development Grant: IS-5196-19, and California Agricultural Experiment Station Hatch project: CA-D-PLS-2164-H (DB).

Begum, N., Qin, C., Ahanger, M. A., Raza, S., Khan, M. I., Ashraf, M., et al. (2019). Role of arbuscular mycorrhizal fungi in plant growth regulation: implications in abiotic stress tolerance. Front. Plant Sci. 10:1068. doi: 10.3389/fpls.2019.01068

Belcher, M. S., Vuu, K. M., Zhou, A., Mansoori, N., Ramos, A. A., Thompson, M. G., et al. (2020). Design of orthogonal regulatory systems for modulating gene expression in plants. Nat. Chem. Biol. 16:857. doi: 10.1038/s41589-0200547-4

Bengtson, P., Barker, J., and Grayston, S. J. (2012). Evidence of a strong coupling between root exudation, $\mathrm{C}$ and $\mathrm{N}$ availability, and stimulated SOM decomposition caused by rhizosphere priming effects. Ecol. Evol. 2, 1843-1852. doi: 10.1002/ece 3.311

Berazneva, J., Conrad, J. M., Guerena, D. T., Lehman, J., and Woolf, D. (2019). Agricultural prodcutivity and soil carbon dynamics: a bioeconomic model. Am. J. Agric. Econ. 101, 1021-1046. doi: 10.1093/ajae/aaz014

Berger, J. J. (2019). Can soil microbes slow climate change? Sci. Am. Available online at:https://www.scientificamerican.com/article/can-soil-microbes-slowclimate-change/

Bloom, A. J., Chapin, F. S., and Mooney, H. A. (1985). Resource limitation in plants - an economic analogy. Annu. Rev. Ecol. Syst. 16, 363-392. doi: 10.1146/ annurev.es.16.110185.002051

Burnett, A. C., Rogers, A., Rees, M., and Osborne, C. P. (2016). Carbon source-sink limitations differ between two species with contrasting growth strategies. Plant Cell Environ. 39, 2460-2472. doi: 10.1111/pce.12801

Chang, T.-G., and Zhu, X.-G. (2017). Source-sink interaction: a century old concept under the light of modern molecular systems biology. J. Exp. Bot. 68:1002. doi: $10.1093 / \mathrm{xb} / \mathrm{erx} 1002$

Churland, C., and Grayston, S. J. (2014). Specificity of plant-microbe interactions in the tree mycorrhizosphere biome and consequences for soil $\mathrm{C}$ cycling. Front. Microbiol. 5:261. doi: 10.3389/fmicb.2014.00261

Cotrufo, M. F., Wallenstein, M. D., Boot, C. M., Denef, K., and Paul, E. (2013). The Microbial Efficiency-Matrix Stabilization (MEMS) framework integrates plant litter decomposition with soil organic matter stabilization: do labile plant 
inputs form stable soil organic matter? Glob. Change Biol. 19, 988-995. doi: $10.1111 / \mathrm{gcb} .12113$

De Deyn, G. B., Shiel, R. S., Ostle, N. J., McNamara, N. P., Oakley, S., Young, I., et al. (2011). Additional carbon sequestration benefits of grassland diversity restoration. J. Appl. Ecol. 48, 600-608. doi: 10.1111/j.1365-2664.2010.01925.x

de Souza, R. S. C., Armanhi, J. S. L., and Arruda, P. (2020). From microbiome to traits: designing synthetic microbial communities for improved crop resiliency. Front Plant Sci 11:1179. doi: 10.3389/fpls.2020.01179

DOE, (2008). Carbon Cycling and Biosequestration: Integrating Biology and Climate Through Systems Science. U.S. Department of Energy Office of Science. Available online at: http://genomicsgtl.energy.gov/carboncycle/ (accessed March 2008).

Economist, T. (2017). Sucking up Carbon. Greenhouse Gases Must be Scrubbed From the Air. Available online at: http://www.economist.com/news/briefing/ 21731386-cutting-emissions- will-not-be-enough-keep-global-warmingcheck- greenhouse- gases- must-be? frsc $=\mathrm{dg} \% 7 \mathrm{Ce}$ (accessed December 5, 2020).

Faiola, C. L., Buchholz, A., Kari, E., Yli-Pirila, P., Holopainen, J. K., Kivimäenpää, M., et al. (2018). Terpene composition complexity controls secondary organic aerosol yields from scots pine volatile emissions. Sci. Rep. 8:21045. doi: 10.1038/ s41598-018-21045-1

Faiola, C. L., Pullinen, I., Buchholz, A., Khalaj, F., Ylisirnio, A., Kari, E., et al. (2019). Secondary organic aerosol formation from healthy and aphid-stressed scots pine emissions. Acs Earth Space Chem. 3, 1756-1772. doi: 10.1021/ acsearthspacechem.9b00118

Fan, F. L., Zhang, F. S., Qu, Z., and Lu, Y. H. (2008). Plant carbon partitioning below ground in the presence of different neighboring species. Soil Biol. Biochem. 40, 2266-2272. doi: 10.1016/j.soilbio.2008.05.003

Flexas, J., Díaz-Espejo, A., Conesa, M. A., Coopman, R. E., Douthe, C., Gago, J., et al. (2016). Mesophyll conductance to $\mathrm{CO} 2$ and Rubisco as targets for improving intrinsic water use efficiency in C3 plants. Plant Cell Environ. 39, 965-982. doi: 10.1111/pce.12622

Glover, J. D., Cox, C. M., and Reganold, J. P. (2007). Future FArming: a return to roots? Sci. Am. 2007, 82-89.

Gorzelak, M. A., Assay, A. K., Pickles, B. J., and Simard, S. W. (2015). Inter-plant communication through mycorrhizal networks mediates complex adaptive behaviour in plant communities. AOB Plants 7:lv050. doi: 10.1093/aobpla/ plv050

Grafahrend-Belau, E., Junker, A., Eschenroeder, A., Muller, J., Schreiber, F., and Junker, B. (2013). Multiscale metabolic modeling: dynamic flux balance analysis on a whole-plant scale. Plant Physiol. 163, 637-647. doi: 10.1104/pp.113.224006

Griscom, B. W., Adams, J., Ellis, P. W., Houghton, R. A., Lomax, G., Miteva, D. A., et al. (2017). Natural climate solutions. Proc. Natl. Acad. Sci. U.S.A. 114 11645-11650. doi: 10.1073/pnas.1710465114

Guenther, A. B., Jiang, X., Heald, C. L., Sakulyanontvittaya, T., Duhl, T., Emmons, L. K., et al. (2012). The model of emissions of gases and aerosols from nature version 2.1 (MEGAN2.1): an extended and updated framework for modeling biogenic emissions. Geosci. Model. Dev. 5, 1471-1492. doi: 10.5194/gmd-51471-2012

Guo, Y., Wang, X. J., Li, X. L., Wang, J. P., Xu, M. G., Li, D. W., et al. (2016) Dynamics of soil organic and inorganic carbon in the cropland of upper Yellow River Delta, China. Sci. Rep. 6:36105. doi: 10.1038/srep36105

Hallama, M., Pekrun, C., Lambers, H., and Kandeler, E. (2019). Hidden miners the roles of cover crops and soil microorganisms in phosphorus cycling through agroecosystems. Plant Soil 434, 7-45. doi: 10.1007/s11104-0183810-7

Hallquist, M., Wenger, J. C., Baltensperger, U., Rudich, Y., Simpson, D., Claeys, M., et al. (2009). The formation, properties and impact of secondary organic aerosol: current and emerging issues. Atmos. Chem. Phys. 9, 5155-5236. doi: 10.5194/acp-9-5155-2009

Harley, P. C., Monson, R. K., and Lerdau, M. T. (1999). Ecological and evolutionary aspects of isoprene emission from plants. Oecologia 118, 109-123. doi: 10.1007/ s004420050709

Helliwell, J. R., Sturrock, C. J., Miller, A. J., Whalley, W. R., and Mooney, S. J. (2019). The role of plant species and soil condition in the structural development of the rhizosphere. Plant Cell Environ. 42, 1974-1986. doi: 10. $1111 /$ pce. 13529

Holopainen, J. K., and Gershenzon, J. (2010). Multiple stress factors and the emission of plant VOCs. Trends Plant Sci. 15, 176-184. doi: 10.1016/j.tplants. 2010.01.006
Houghton, R. A., and Nassikas, A. A. (2017). Global and regional fluxes of carbon from land use and land cover change 1850-2015. Glob. Biogeochem. Cycles 31, 456-472. doi: 10.1002/2016gb005546

Hungate, B. A., Holland, E. A., Jackson, R. B., Chapin, F. S., Mooney, H. A., and Field, C. B. (1997). The fate of carbon in grasslands under carbon dioxide enrichment. Nature 388, 576-579. doi: 10.1038/41550

Jansson, C., Vogel, J., Hazen, S., Brutnell, T., and Mockler, T. (2018). Climatesmart crops with enhanced photosynthesis. J. Exp. Bot. 69, 3801-3809. doi: $10.1093 / \mathrm{jxb} /$ ery 213

Jansson, C., Wullschleger, S. D., Udaya, C. K., and Tuskan, G. A. (2010). Phytosequestration: carbon biosequestration by plants and the prospects of genetic engineering. Bioscience 60, 685-696. doi: 10.1525/bio.2010.60.9.6

Jantke, K., Hartmann, M. J., Rasche, L., Blanz, B., and Schneider, U. A. (2020). Agricultural greenhouse gas emissions: knowledge and positions of german farmers. Land 9:130.

Jastrow, J. D., Miller, R. M., Matamala, R., Norby, R. J., Boutton, T. W., Rice, C. W., et al. (2005). Elevated atmospheric carbon dioxide increases soil carbon. Glob. Change Biol. 11, 2057-2064. doi: 10.1111/j.1365-2486.2005.01077.x

Joutsensaari, J., Yli-Pirila, P., Korhonen, H., Arola, A., Blande, J. D., Heijari, J., et al. (2015). Biotic stress accelerates formation of climate-relevant aerosols in boreal forests. Atmos Chem. Phys. 15, 12139-12157. doi: 10.5194/acp-15-121392015

Kaiser, C., Kilburn, M. R., Clode, P. L., Fuchslueger, L., Koranda, M., Cliff, J. B., et al. (2015). Exploring the transfer of recent plant photosynthates to soil microbes: mycorrhizal pathway vs direct root exudation. New Phytol. 205, 1537-1551. doi: $10.1111 /$ nph. 13138

Kallenbach, C. M., Frey, S. D., and Grandy, A. S. (2016). Direct evidence for microbial-derived soil organic matter formation and its ecophysiological controls. Nat. Commun. 7:13630.

Kaschuk, G., Kuyper, T. W., Leffelaar, P. A., Hungria, M., and Giller, K. E. (2009). Are the rates of photosynthesis stimulated by the carbon sink strength of rhizobial and arbuscular mycorrhizal symbioses? Soil Biol. Biochem. 41, 1233-1244. doi: 10.1016/j.soilbio.2009.03.005

Keiluweit, M., Bougoure, J. J., Nico, P. S., Pett-Ridge, J., Weber, P. K., and Kleber, M. (2015). Mineral protection of soil carbon counteracted by root exudates. Nat. Clim. Change 5, 588-595.

Kell, D. B. (2012). Large-scale sequestration of atmospheric carbon via plant roots in natural and agricultural ecosystems: why and how. Philos. Transact. R. Soc. B Biol. Sci. 367, 1589-1597. doi: 10.1098/rstb.2011.0244

Kerminen, V. M., Lihavainen, H., Komppula, M., Viisanen, Y., and Kulmala, M. (2005). Direct observational evidence linking atmospheric aerosol formation and cloud droplet activation. Geophys. Res. Lett. 32:23130. doi: 10.1029/ 2005gl023130

Kravchenko, A. N., Guber, A. K., Razavi, B. S., Koestel, J., Quigley, M. Y., Robertson, G. P., et al. (2019). Microbial spatial footprint as a driver of soil carbon stabilization (vol 10, 3121, 2019). Nat. Commun. 10:12000.

Kromdijk, J., Głowacka, K., Leonelli, L., Gabilly, S. T., Iwai, M., Niyogi, K. K., et al. (2016). Improving photosynthesis and crop productivity by accelerating recovery from photoprotection. Science 354:857.

Kuzyakov, Y., and Domanski, G. (2000). Carbon input by plants into the soil. Review. J. Plant Nutr. Soil Sci. 163, 421-431. doi: 10.1002/1522-2624(200008) 163:4<421::Aid-Jpln421<3.0.Co;2-R

Lakshmanan, M., Cheung, C. Y. M., Mohanty, B., and Lee, D. Y. (2016). Modeling rice metabolism: from elucidating environmental effects on cellular phenotype to guiding crop improvement. Front. Plant Sci. 7:1795. doi: 10.3389/fpls.2016. 01795

Lal, R. (2004a). Soil carbon sequestration impacts on global climate change and food security. Science 304, 1623-1627.

Lal, R. (2004b). Soil carbon sequestration to mitigate climate change. Geoderma 123, 1-22. doi: 10.1016/j.geoderma.2004.01.032

Lal, R. (2008). Sequestration of atmospheric CO2 in global carbon pools. Ener. Environ. Sci. 1, 86-100. doi: 10.1039/b809492f

Lange, M., Eisenhauer, N., Sierra, C. A., Bessler, H., Engels, C., Griffiths, R. I., et al. (2015). Plant diversity increases soil microbial activity and soil carbon storage. Nat. Commun. 6:7707. doi: 10.1038/ncomms 7707

Lawson, T., and Blatt, M. R. (2014). Stomatal size, speed, and responsiveness impact on photosynthesis and water use efficiency. Plant Physiol. 164, 1556-1570. doi: $10.1104 /$ pp.114.237107 
Le Quere, C., Andrew, R. M., Friedlingstein, P., Sitch, S., Hauck, J., Pongratz, J., et al. (2018). Global carbon budget 2018. Earth Syst. Sci. Data 10, 2141-2194. doi: 10.5194/essd-10-2141-2018

Lenaerts, B., Collard, B. C. Y., and Demont, M. (2019). Review: Improving global food security through accelerated plant breeding. Plant Sci. 287, 110207. doi: 10.1016/j.plantsci.2019.110207

Long, S. P., Marshall, A. M., and Zhu, X. G. (2015). Engineering crop photosynthesis and yield potential to meet global food demand of 2050. Cell $161,56-66$.

Lorenz, K., Lal, R., and Shipitalo, M. J. (2008). Chemical stabilization of organic carbon pools in particle size fractions in no-till and meadow soils. Biol. Fertility Soils 44, 1043-1051.

Loreto, F., and Sharkey, T. D. (1993). Isoprene emission by plants is affected by transmissible wound signals. Plant Cell Environ. 16, 563-570. doi: 10.1111/j. 1365-3040.1993.tb00904.x

Ma, F., Jazmin, L. J., Young, J. D., and Allen, D. K. (2014). Isotopically nonstationary $13 \mathrm{C}$ flux analysis of changes in Arabidopsis thaliana leaf metabolism due to high light acclimation. Proc. Natl. Acad. Sci. U.S.A. 111:16967. doi: 10.1073/pnas.1319485111

Matthews, M. L., and Marshall-Colon, A. (2021). Multiscale plant modeling: from genome to phenome and beyond. Emerg. Top. Life Sci. 5:ETLS20200276. doi: 10.1042/ETLS20200276

Mentel, T. F., Kleist, E., Andres, S., Dal Maso, M., Hohaus, T., Kiendler-Scharr A., et al. (2013). Secondary aerosol formation from stress-induced biogenic emissions and possible climate feedbacks. Atmos Chem. Phys. 13, 8755-8770. doi: 10.5194/acp-13-8755-2013

Mohr, C., Thornton, J. A., Heitto, A., Lopez-Hilfiker, F. D., Lutz, A., Riipinen, I., et al. (2019). Molecular identification of organic vapors driving atmospheric nanoparticle growth. Nat. Commun. 10:12473. doi: 10.1038/s41467-01912473-2

Mokany, K., Raison, R. J., and Prokushkin, A. S. (2006). Critical analysis of root : shoot ratios in terrestrial biomes. Glob. Change Biol. 12, 84-96. doi: 10.1111/j. 1365-2486.2005.001043.x

Mwafulirwa, L., Baggs, E. M., Russell, J., George, T., Morley, N., Sim, A., et al. (2016). Barley genotype influences stabilization of rhizodeposition-derived C and soil organic matter mineralization. Soil Biol. Biochem. 95, 60-69. doi: 10. 1016/j.soilbio.2015.12.011

Naveed, M., Brown, L. K., Raffan, A. C., George, T. S., Bengough, A. G., Roose, T., et al. (2017). Plant exudates may stabilize or weaken soil depending on species, origin and time. Eur. J. Soil Sci. 68, 806-816. doi: 10.1111/ejss. 12487

Niinemets, U. (2010). Mild versus severe stress and BVOCs: thresholds, priming and consequences. Trends Plant Sci. 15, 145-153. doi: 10.1016/j.tplants.2009. 11.008

Niinemets, U., Kannaste, A., and Copolovici, L. (2013). Quantitative patterns between plant volatile emissions induced by biotic stresses and the degree of damage. Front. Plant Sci. 4:262.

Ort, D. R., Merchant, S. S., Alric, J., Barkan, A., Blankenship, R. E., Bock, R., et al. (2015). Redesigning photosynthesis to sustainably meet global food and bioenergy demand. Proc. Natl. Acad. Sci. U.S.A. 112, 8529-8536. doi: 10.1073/ pnas. 1424031112

Paustian, K., Campbell, N., Dorich, C., Marx, E., and Swan, A. (2016). Assessment of Potential Greenhouse Gas Mitigation From Chanes to Crop Root Mass and Architecture. Final Report fo ARPA-E; Independent Consultant Agreement \#107142CL/CB0471 - Booz Allen Hamilton Inc. Available online at: https://arpa-e.energy.gov/sites/default/files/documents/files/Revised Final_Report_to_ARPA_Bounding_Analysis.pdf (accessed December 5, 2020).

Paustian, K., Collier, S., Baldock, J., Burgess, R., Creque, J., DeLonge, M., et al. (2019a). Quantifying carbon for agricultural soil management: from the current status toward a global soil information system. Carbon. Manag. 10, 567-587. doi: 10.1080/17583004.2019.1633231

Paustian, K., Larson, E., Kent, J., Marx, E., and Swan, A. (2019b). Soil C sequestration as a biological negative emission strategy. Front. Climate 1:8. doi: $10.3389 /$ fclim.2019.00008

Pendall, E., Mosier, A. R., and Morgan, J. A. (2004). Rhizodeposition stimulated by elevated CO2 in a semiarid grassland. New Phytol. 162, 447-458. doi: 10.1111/j. 1469-8137.2004.01054.x
Phillips, R. P., Meier, I. C., Bernhardt, E. S., Grandy, A. S., Wickings, K., and Finzi, A. C. (2012). Roots and fungi accelerate carbon and nitrogen cycling in forests exposed to elevated CO2. Ecol. Lett. 15, 1042-1049. doi: 10.1111/j.1461-0248. 2012.01827.x

Poeplau, C., and Don, A. (2015). Carbon sequestration in agricultural soils via cultivation of cover crops - A meta-analysis. Agricult. Ecosyst. Environ. 200, 33-41. doi: 10.1016/j.agee.2014.10.024

Poorter, H., and Nagel, O. (2000). The role of biomass allocation in the growth response of plants to different levels of light, $\mathrm{CO}_{2}$, nutrients and water: a quantitative review. Aust. J. Plant Physiol. 27, 595-607. doi: 10.1071/Pp99173

Postma, J. A., Kuppe, C., Owen, M. R., Mellor, N., Griffiths, M., Bennett, M. J., et al. (2017). OPENSIMROOT: widening the scope and application of root architectural models. New Phytol. 215, 1274-1286. doi: 10.1111/nph.14641

Poyda, A., Wizemann, H. D., Ingwersen, J., Eshonkulov, R., Hogy, P., Demyan, M. S., et al. (2019). Carbon fluxes and budgets of intensive crop rotations in two regional climates of southwest Germany. Agricult. Ecosyst. Environ. 276, 31-46. doi: 10.1016/j.agee.2019.02.011

Rap, A., Scott, C. E., Reddington, C. L., Mercado, L., Ellis, R. J., Garraway, S. A., et al. (2018). Enhanced global primary production by biogenic aerosol via diffuse radiation fertilization. Nat. Geosci. 11:640. doi: 10.1038/s41561-0180208-3

Riipinen, I., Yli-Juuti, T., Pierce, J. R., Petaja, T., Worsnop, D. R., Kulmala, M., et al. (2012). The contribution of organics to atmospheric nanoparticle growth. Nat. Geosci. 5, 453-458. doi: 10.1038/ngeo1499

Sanderman, J., and Baldock, J. A. (2010). Accounting for soil carbon sequestration in national inventories: a soil scientist's perspective. Environ. Res. Lett. 5:34003. doi: 10.1088/1748-9326/5/3/034003

Sanderman, J., Farquharson, R., and Baldock, J. A. (2010). Soil Carbon Sequestration Potential: A Review for Australian Agriculture. Available online at: www.csiro.au/resources/Soil-Carbon-Sequestration-Potential-Report.html (accessed December 5, 2020).

Sanderman, J., Hengl, T., and Fiske, G. J. (2017). Soil carbon debt of 12,000 years of human land use. Proc. Natl. Acad. Sci. U.S.A. 114, 9575-9580. doi: 10.1073/ pnas. 1706103114

Schmidt, M., Reichenau, T. G., Fiener, P., and Schneider, K. (2012). The carbon budget of a winter wheat field: an eddy covariance analysis of seasonal and inter-annual variability. Agricult. For. Meteorol. 165, 114-126. doi: 10.1016/j. agrformet.2012.05.012

Serrago, R. A., Alzueta, I., Savin, R., and Slafer, G. A. (2013). Understanding grain yield responses to source-sink ratios during grain filling in wheat and barley under contrasting environments. Field Crops Res. 150, 42-51. doi: 10.1016/j.fcr. 2013.05.016

Sharkey, T. D., and Loreto, F. (1993). Water-stress, temperature, and light effects on the capacity for isoprene emission and photosynthesis of kudzu leaves. Oecologia 95, 328-333. doi: 10.1007/Bf00320984

Six, J., Conant, R. T., Paul, E. A., and Paustian, K. (2002). Stabilization mechanisms of soil organic matter: implications for C-saturation of soils. Plant Soil 241, 155-176. doi: 10.1023/A:1016125726789

South, P. F., Cavanagh, A. P., Liu, H. W., and Ort, D. R. (2019). Synthetic glycolate metabolism pathways stimulate crop growth and productivity in the field. Science 363:9077. doi: 10.1126/science.aat9077

Spracklen, D. V., Carslaw, K. S., Kulmala, M., Kerminen, V.-M., Sihto, S.-L., Riipinen, I., et al. (2008). Contribution of particle formation to global cloud condensation nuclei concentrations. Geophys. Res. Lett. 35:33038. doi: 10.1029/ $2007 \mathrm{gl} 1033038$

Steinbeiss, S., Bessler, H., Engels, C., Temperton, V. M., Buchmann, N., Roscher, C., et al. (2008). Plant diversity positively affects short-term soil carbon storage in experimental grasslands. Glob. Change Biol. 14, 2937-2949. doi: 10.1111/j. 1365-2486.2008.01697.x

Sweetlove, L. J., and Ratcliffe, R. G. (2011). Flux-balance modeling of plant metabolism. Front. Plant Sci. 2:38. doi: 10.3389/fpls.2011.00038

Taylor, S. H., and Long, S. P. (2017). Slow induction of photosynthesis on shade to sun transitions in wheat may cost at least $21 \%$ of productivity. Philos. Transact. R. S. B Biol. Sci. 372:20160543. doi: 10.1098/rstb.2016.0543

The Carbon Cycle Institute (2020). Carbon Farming. Available online at: http: //www.carboncycle.org/\%20carbon-farming/ (accessed December 5, 2020).

Thornley, J. H. (1972). Model to describe partitioning of photosynthate during vegetative plant-growth. Ann. Bot. 36, 419. 
Töpfer, N., Braam, T., Shameer, S., Ratcliffe, R. G., and Sweetlove, L. J. (2020). Alternative crassulacean acid metabolism modes provide environment-specific water-saving benefits in a leaf metabolic model. Plant Cell 32, 3689-3705. doi: $10.1105 /$ tpc.20.00132

Trivedi, P., Anderson, I. C., and Singh, B. K. (2013). Microbial modulators of soil carbon storage: integrating genomic and metabolic knowledge for global prediction. Trends Microbiol. 21, 641-651. doi: 10.1016/j.tim.2013.09.005

Turner, T. R., James, E. K., and Poole, P. S. (2013). The plant microbiome. Genome Biol. 14:209.

U.S. Geological Survey (USGS), (2019). Global Food Security-Support Analysis Data at $30 \mathrm{~m}$. Available online at: https://www.usgs.gov/centers/wgsc/science/ global-food-security-support-analysis-data-30-m?qt-science_center_objects= 0\#qt-science_center_objects (accessed December 5, 2020).

Uren, N. C. (2007). The Rhizosphere, eds R. Pinton, Z. Varanini, and P. Nannipieri (Boca Raton, FL: CRC Press), 1-23.

Voges, M. J. E. E. E., Bai, Y., Schulze-Lefert, P., and Sattely, E. S. (2019). Plantderived coumarins shape the composition of an Arabidopsis synthetic root microbiome. Proc. Natl. Acad. Sci. U.S.A. 116, 12558-12565. doi: 10.1073/pnas. 1820691116

Voss-Fels, K. P., Stahl, A., and Hickey, L. T. (2019). Q\&A: modern crop breeding for future food security. BMC Biol. 17:638. doi: 10.1186/s12915-019-0638-4

White, A. C., Rogers, A., Rees, M., and Osborne, C. P. (2016). How can we make plants grow faster? A source-sink perspective on growth rate. J. Exp. Bot. 67, 31-45. doi: 10.1093/jxb/erv447

Wiechert, W. (2001). 13C metabolic flux analysis. Metab Eng 3, 195-206. doi: 10.1006/mben.2001.0187

Yang, Y., Tilman, D., Furey, G., and Lehman, C. (2019). Soil carbon sequestration accelerated by restoration of grassland biodiversity. Nat. Commun. 10:8636. doi: 10.1038/s41467-019-08636-w
Yli-Pirilä, P., Copolovici, L., Kännaste, A., Noe, S., Blande, J. D., Mikkonen, S., et al. (2016). Herbivory by an outbreaking moth increases emissions of biogenic volatiles and leads to enhanced secondary organic aerosol formation capacity. Environ. Sci. Technol. 50, 11501-11510. doi: 10.1021/acs.est.6b02800

Zhang, H. Q., Liu, T., Wang, Y. Y., and Tang, M. (2019). Exogenous arbuscular mycorrhizal fungi increase soil organic carbon and change microbial community in poplar rhizosphere. Plant Soil Environ. 65, 152-158. doi: 10. 17221/2/2019-Pse

Zhao, D. F., Buchholz, A., Tillmann, R., Kleist, E., Wu, C., Rubach, F., et al. (2017). Environmental conditions regulate the impact of plants on cloud formation. Nat. Commun. 8:14067. doi: 10.1038/ncomms 14067

Zsögön, A., Čermák, T., Voytas, D., and Peres, L. E. P. (2017). Genome editing as a tool to achieve the crop ideotype and de novo domestication of wild relatives: case study in tomato. Plant Sci. 256, 120-130. doi: 10.1016/j.plantsci.2016. 12.012

Conflict of Interest: The authors declare that the research was conducted in the absence of any commercial or financial relationships that could be construed as a potential conflict of interest.

Copyright (C) 2021 Jansson, Faiola, Wingler, Zhu, Kravchenko, de Graaff, Ogden, Handakumbura, Werner and Beckles. This is an open-access article distributed under the terms of the Creative Commons Attribution License (CC BY). The use, distribution or reproduction in other forums is permitted, provided the original author(s) and the copyright owner(s) are credited and that the original publication in this journal is cited, in accordance with accepted academic practice. No use, distribution or reproduction is permitted which does not comply with these terms. 